\title{
8. MORPHOLOGY, MICROPHYSIOGRAPHY, SEDIMENTARY, AND BIOLOGY PATTERNS OF SURFICIAL DEPOSITS IN THE SOUTH BARBADOS PRISM: RECORD OF RECENT AND PRESENT ACTIVE TECTONICS1
}

\author{
Jean Claude Faugères, ${ }^{2}$ Eliane Gonthier, ${ }^{2}$ Roger Griboulard, ${ }^{2}$ Didier Jollivet, ${ }^{3}$ and Georges Vernette ${ }^{2}$
}

\begin{abstract}
The morphologic complexity of the southern part of the Barbados prism is the reflection of the numerous structural patterns that coexist within this zone located at the crossroad of three domains: the Atlantic Plate, the Caribbean domain, and the Venezuelan margin.

The analyses of Sea-Beam maps, 3.5-kHz profiles, submarine photographs, and Kullenberg cores allowed us to define different types of morpho-sedimentary domains as well as their surface patterns, echofacies, lithology, and origin of the surficial deposits, and the settling processes. Five types of domains can be distinguished: NE-SW anticlinal ridges; mud volcanoes that can be isolated, dispersed, or aligned in a N-S direction; basins; deformed depressions; and canyons. The morphology of these domains records their recent tectonic evolution. 1. NW-SE syncline depressions are intersected by NE-SW anticline ridges or faults. 2. Anticline ridges are sometimes sigmoid in shape as a consequence of the E-W movement of transcurrent faults. 3. Deformed crescent-shaped depressions are also due to the E-W accidents. 4. The course and the depth of the canyons can be modified according to the evolution of the domains that they traverse. 5. The sub-bottom reflectors and the echofacies are disturbed along the tectonic contact between the different domains.

Analysis of surficial deposits highlights the dominance of turbidity currents in the basin. These currents flow through very young and strongly incised canyons, connected to those of the Venezuelan margin and the Orinoco River. Evidence of bottom-current activity is recorded in deposits of structural relief that show ripple-mark fields and erosional furrows at their base. On the mud volcanoes and on the anticlinal ridges, argilokinetic processes manifest themselves by the uplifted ancient material (Miocene to Quaternary) present in the surficial deposits. This material could be introduced into the basin deposits by gravity flows, triggered on the steep slopes of structural reliefs.

Surface pattern details on top of these reliefs usually show indurated surfaces upon which deep-sea fauna are locally observed. The presence of these litho-biological features is linked to diagenetic and biochemical processes that depend on "cold seeps." They are distributed along NE-SW and E-W tectonic structures that are the most active in the South Barbados prism.
\end{abstract}

\section{INTRODUCTION}

The accretionary prism of Barbados formed by the subduction of the Atlantic Plate beneath the Caribbean Plate has been the subject of much research (Biju-Duval et al., 1982; Westbrook et al., 1982, 1984; Fontas et al., 1984; Ngokwey et al., 1984; Mauffret et al., 1984). After the Carven cruises of the Comite d'Etudes Pétrolières Marines, France, morphological and highresolution seismic studies were carried out (Valery et al., 1985; Fontas et al., 1985). They showed the complexity of the structures of the accretionary prism as well as its style of deformation and the sedimentary processes. They emphasized the relationship between a very contrasting morphology and the internal mechanisms that have, at least partially, created it.

Recently, the Caracolante II (1985) and Diapicar I (1987) cruises allowed a detailed analysis of the southern part of the prism (Fig. 1). Compared with the more northern part, this zone shows different characters. In fact, structurally speaking, it is situated on top of a complex contact zone between different geodynamical domains: the oceanic crust of the Atlantic Plate plunges westward under the Caribbean Plate and generates an island arc (Bouysse, 1984); the southern fringe of the Caribbean Plate overthrusts upon the South American craton, in a NW-SE

\footnotetext{
${ }^{1}$ Moore, J. C., Mascle, A., et al., 1990. Proc. ODP, Sci. Results, 110: College Station, TX (Ocean Drilling Program).

2 Département de Géologie et d'océanographie, U.A 197, Avenue des Facultés, Talence, 33405, France.

3 IFREMER, Centre de Brest, B.P. 70, Plouzané, 29263, France.
}

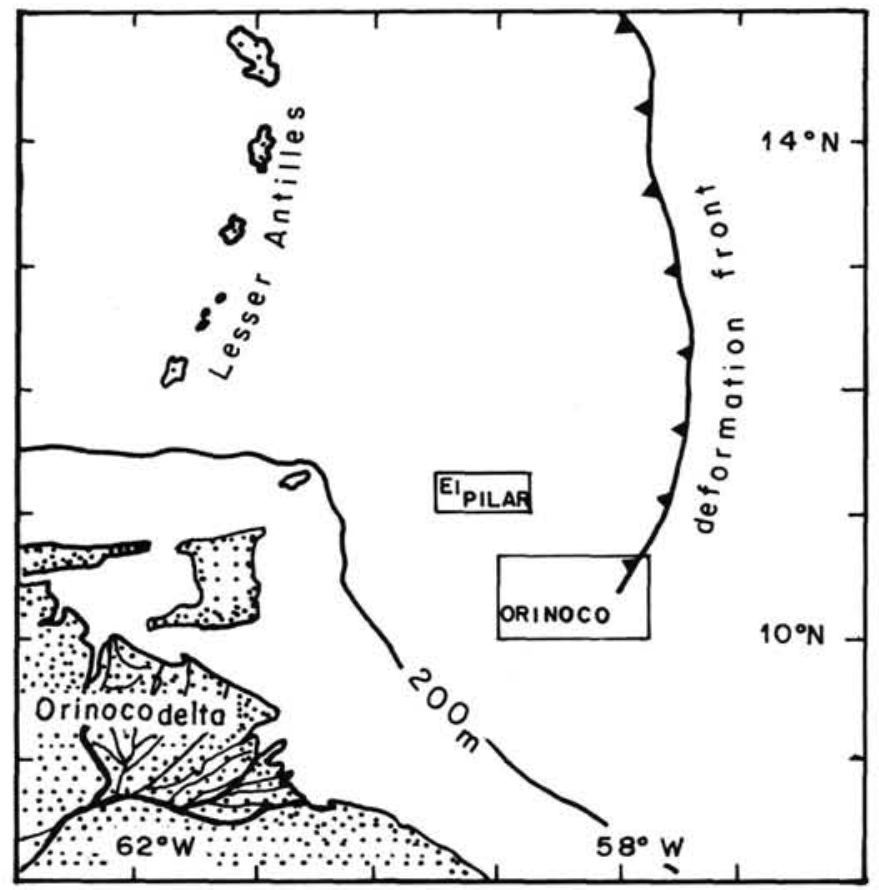

Figure 1. Location map of the bathymetric survey. 
movement. As a consequence, the Venezuelan margin is deformed by E-W transcurrent faults (Butterlin, 1977; Aubouin et al., 1980; Stephan et al., 1985). The intergrowth of these structures produces an important dislocation of the sedimentary deposits that are transformed into a morpho-structural mosaic composed of units of limited extent: disrupted folds with a variable direction and dip, more or less deformed basins of varying size and geometry, mud volcanoes, and other frequent mud diapiric manifestations (Higgins and Saunders, 1974; Westbrook et al., 1984; Fontas et al., 1985; Valery et al., 1985; Mascle et al., 1985). Additionally, the southern part of the prism is subjected to an important continental supply, at least during certain geological periods, that arrives from the Orinoco River or even from the Amazon River (Embley et al., 1970; Damuth and Hayes, 1977; Embley and Langseth, 1977; Poutiers et al., 1983; Leonard, 1983; Belderson et al., 1984; Wright, 1984). To each of these individualized morpho-structural domains is attached particular sedimentary characters.

This study was conducted in two different and limited sectors for which we utilized bathymetric Sea-Beam maps (Valéry et al.,1985): Orinoco map (between $10^{\circ} 00^{\prime}$ and $10^{\circ} 35^{\prime} \mathrm{N}$ latitude, and $57^{\circ} 50^{\prime}$ and $59^{\circ} 00^{\prime} \mathrm{W}$ longitude, Fig. 2) and El Pilar map (between $11^{\circ} 00^{\prime}$ and $11^{\circ} 16^{\prime} \mathrm{N}$ in latitude, and $59^{\circ} 00^{\prime}$ and $59^{\circ} 35^{\prime} \mathrm{W}$ in longitude, Fig. 3). It includes, in addition to the Sea-Beam data, numerous $3.5-\mathrm{kHz}$ profiles and submarine photographs as well as surficial sediment samples. These data allow a more detailed analysis of the general morphology and surface patterns of the deposits in regard to the nature of the sediments. They show the great variety of morpho-sedimentary domains in this part of the prism as well as the distribution of sediments in a broken-up underwater landscape. These data also show the respective role of the gravity flows and bottom currents in sedimentary dynamics. Finally, they shed new light on the general and local manifestations of recent tectonic structures.

\section{MAJOR MORPHO-SEDIMENTARY DOMAINS}

\section{Consequence of the Prism Structures and Their Activity}

Most of the morpho-sedimentary domains that could be distinguished are distributed according to the four main structural directions recognized in this region (Valery et al., 1985; Fontas et al., 1985; Chennouf, 1987).

A NE-SW direction, parallel to the direction of the deformation front in this end of the prism, corresponds to numerous anticlinal axes that are characterized by elongate and asymmetrical ridges (Fig. 2, no. 1).

A submeridian direction is characterized by aligned mud volcanoes (Fig. 2, no. 2).

A NW-SE direction is marked by a depression that is intercepted by the NE-SW ridges (Fig. 2, no. 4).

An E-W direction is observed, related to major transcurrent faults (Fig. 2, no. 9), that are shown on the surface by the sigmoid shape of a few of the NE-SW ridges (Fig. 2, no. 1b) as well as by the direction of certain canyons (Fig. 2, no. 7 and 7a) and by the semicircular shape of certain elongate depressions (Fig. 3, no. 3).

Among these different directions, there is a mosaic of basins that have evolved on different levels of the slope of the prism as well as very dispersed or isolated mud volcanoes (Fig. 2, no. 3).

According to these structures, five major morpho-sedimentary domains can be distinguished.

\section{NE-SW Anticlinal Ridges}

On the Orinoco map (Fig. 2, no.1; Plate 1.1), these numerous features constitute very accentuated reliefs with a difference in elevation, varying from 250 to $550 \mathrm{~m}$. Spreading over distances of up to $26 \mathrm{~km}$, they are asymmetrical with an eastern slope that is generally the steepest $\left(10^{\circ}\right.$ to $\left.40^{\circ}\right)$. Their crests can be either straight, arched, or sigmoid in shape. Very few examples of

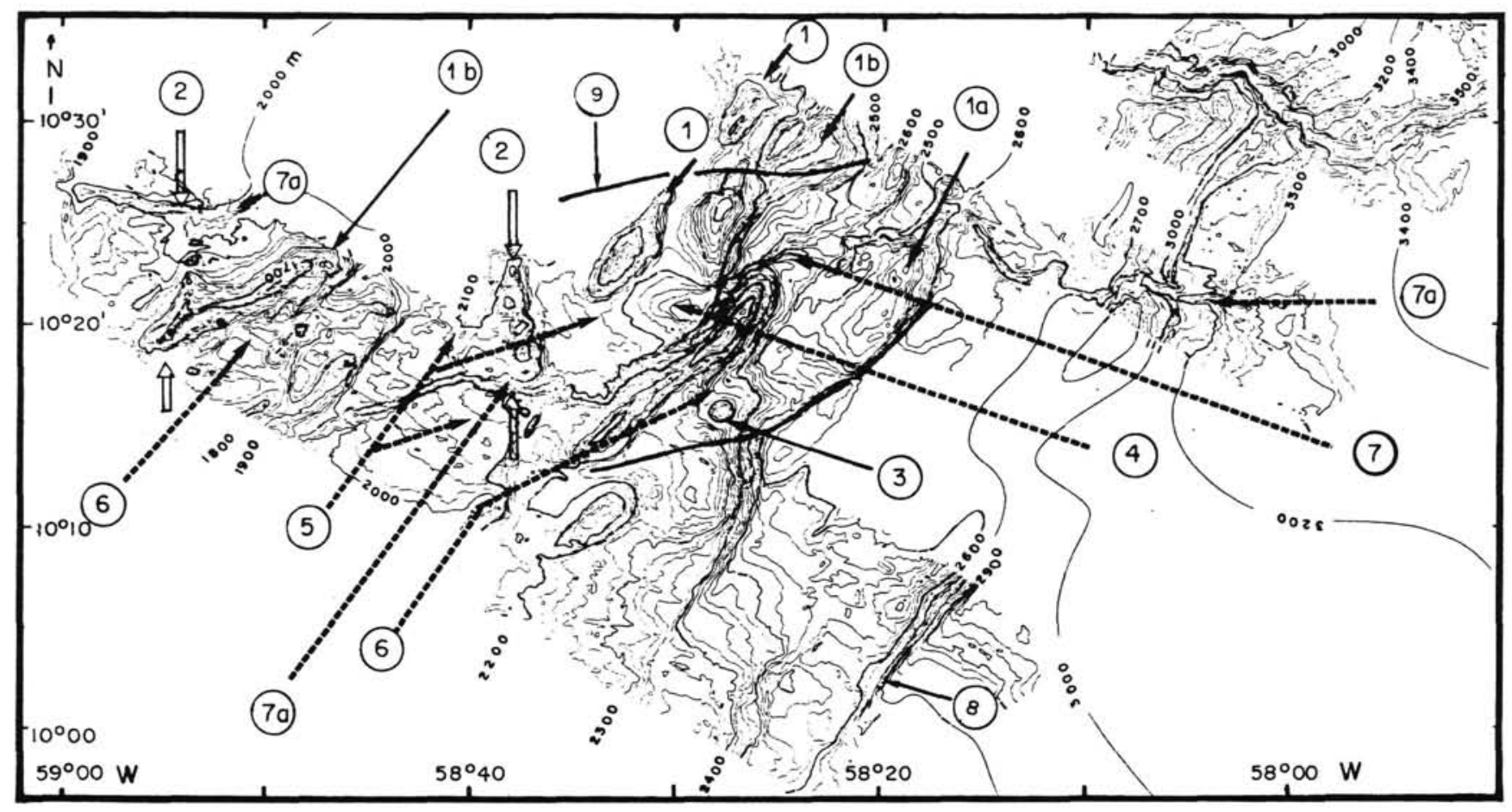

Figure 2. Orinoco Sea-Beam map: morpho-sedimentary domains. 1: Well-individualized NE-SW ridges. la: Poorly individualized NE-SW ridges. $\mathrm{lb}$ : Sigmoid NE-SW ridges. 2: N-S mud volcanoes alignment. 3: Isolated mud volcano. 4: SE-NW depression, cut by a NE-SW ridge. 5: Basins with different bottom elevations intruded by a N-S mud volcano alignment and incised by a deep canyon. 6: Suspended basins. 7: Deep canyons with steep flanks. 7a: E-W canyon sections. 8: Deformation front. 9: Major deep E-W faults. 


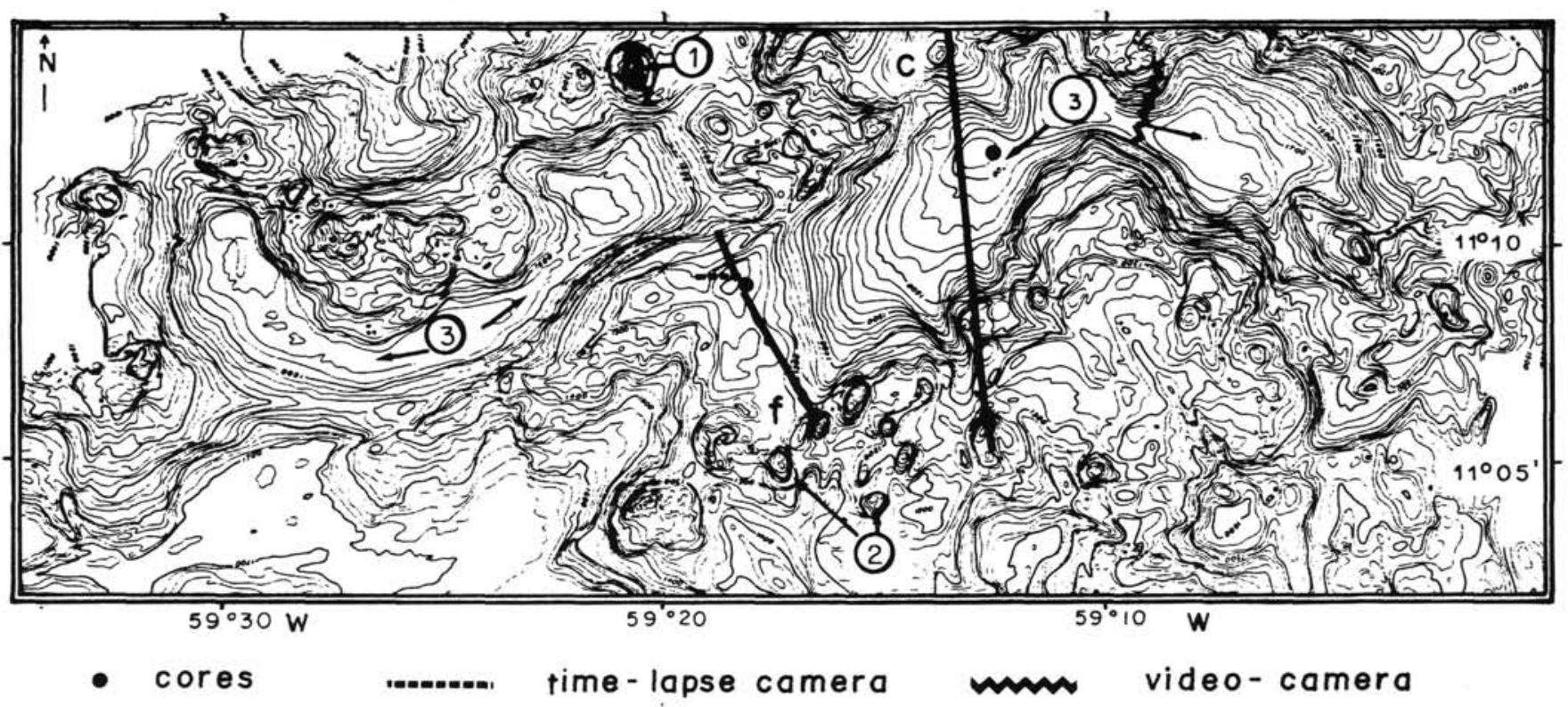

$3,5 \mathrm{Khz}$ profiles (PL-III)

Figure 3. El Pilar Sea-Beam map: morpho-sedimentary domains. 1: Isolated mud volcanoes. 2: Cluster of mud volcanoes. 3: Crescent-shaped depression.

poorly developed ridges were observed (Plate 2.1 and 2.2) and they could correspond to ridges actually being formed or to aborted structures (Fig. 2, no. la).

\section{Mud Volcanoes}

The relief of the mud-volcanoes is one of the manifestations of the argilokinetic processes that are very active on the prism (Chennouf, 1987). They are well defined and generally conical in shape and rise up to $100-250 \mathrm{~m}$ above the neighboring domains (Plate 1.2 and 1.4; Plate 3). Their bases are more or less circular and their diameters range between $\mathrm{I}$ and $4 \mathrm{~km}$; their slopes are relatively steep (upward to $20^{\circ}$ ). Their tops are often stretched according to an E-W or NE-SW direction. Locally, tops can generate an important upwarp relief, much larger than the mud volcano alone. Mud volcanoes are either isolated or grouped (Fig. 2., no. 3 and Fig. 3, no. 2). In this case, they can create N-S alignments (Fig. 2, no. 2; Plate 1.4) or be irregularly distributed (Fig. 3, no. 2). Between proximal volcanoes, suspended sedimentary basins can appear (Plate 3.1 and 3.2). These mud diapirs breach the anticlinal ridges as well as the bottom of the basins.

\section{Basins}

Between the morphologically elevated domains there are intercalated depressions ranging from I to $10 \mathrm{~km}$ in length, with variable shapes. Most of them were interpreted as half-syncline structures, stretched and parallel to the NE-SW ridges. Their western slope disappears as the fold evolves (Chennouf, 1987). Indeed, their origin and their morphology appear more complex. In fact, these synclinal depressions are most often disturbed and intersected by faults or tectonic reliefs of various direction ( $\mathrm{N}-\mathrm{S}$ alignments of mud volcanoes in particular). Consequently, they are broken up into smaller basins (Plate 3.1 and 3.2). They are also cut by deeply indented canyons (Plate 1.2). The basins are on different topographic levels of the prism slope (Plate 1.4) and their floors show a relative dip toward the oceanic plate (Fig. 2, no. 5). They often appear to be suspended in respect to the others and with a difference in elevation of about $100 \mathrm{~m}$ between two contiguous basins (Fig. 2, no. 6; Plate 3.1).
The recent deposits of these basins are either slightly deformed or undeformed with the exception of a sector in which undulating structures are observed (Plate 1.2).

\section{Deformed Depressions}

Two types of depressions have been found. The first type is represented by a single example that is visible in the Orinoco sector (Fig. 2, no.4 and Plate 1.1). It is a large depression (about $6 \mathrm{~km}$ width) that can be followed for about $20 \mathrm{~km}$. It corresponds to an older morphological feature. In fact, it is broken up by a NE-SW ridge into two north and south compartments whose floors are situated at 2280 and $2500 \mathrm{~m}$, respectively. Moreover, the southern compartment is actually limited toward the southwest by a $100-\mathrm{m}$ escarpment due to a recurrent thrust fault oriented in a NE-SW direction. The second type is well illustrated on the El Pilar sector (Fig. 3, no. 3 and Plate 3.3). Here, the deep depressions $(1700 \mathrm{~m})$ show a general crescent shape whose long axis is E-W; the concavity is oriented either to the north or to the south and is linked to a bottom uplift that is characterized by numerous mud volcanoes (rim-syncline, Jackson and Gallaway, 1984).

\section{Canyons}

Several canyons cut the surface of the South Barbados prism. These canyons are the extensions of shallower canyons that cut the continental slope of the Venezuelan margin. The morphological freshness of their incisions is proof of important and recent activity. Coarse-grained terrigenous sediments are transported through them, from the Orinoco River (Plate 1.1 and 1.2; Plate 3.2 and 3.4). They show sinuous courses affected by sudden changes of direction and their depth ranges from 100 $\mathrm{m}$ to more than $200 \mathrm{~m}$ for the main canyon of the Orinoco sector (Fig. 2, no. 7). These variations, as well as the directional changes, are caused by the tectonic activity that affects the prism. Thus, the incision is small through the basins that are not deformed and becomes deeper in the neighborhood of the NE-SW anticline ridges that are actually being uplifted. Moreover, the course of these canyons shows an alternation between $\mathrm{E}-\mathrm{W}, \mathrm{N}-\mathrm{S}$, and NE-SW directions superimposed on the previ- 
ously mentioned major structural directions. This indicates a continuous readjustment of the canyons because of the evolving tectonic structures. This appears in the morphology through the very steep and erosive slopes that cut through even the most recent deposits.

The major morphological characters of the South Barbados prism are determined by the structural characters of this region. They permit us to define several types of domains whose geometry is permanently modified by the recurrence of tectonic activity. These morphological domains of structural origin show differences in their sediment characters. Therefore we discuss the morpho-sedimentary domains whose patterns and surficial deposits can be examined in terms of their echofacies and sedimentary process.

\section{BOTTOM MICROPHYSIOGRAPHY: EVIDENCE OF SEDIMENTARY PROCESSES}

Within a given morphological framework, the deep bottom microphysiography reflects the importance of sediment supplies and settling processes (Damuth and Hayes, 1977; Jacobi, 1982). In the studied area, sediments have varying origins. A major part comes from the Orinoco River and is carried to the prism by a network of canyons (Embley and Langseth, 1977; Belderson et al., 1984). The material varies from medium-sized sand to clayey silty muds with a particular mineralogical assemblage (Van Andel, 1967; Baretto et al., 1975; Eisma et al., 1978; Bowles and Fleisher, 1985). Fine-grained siliclastics supplied from the Amazon River are transported either by surface or bottom currents (Gibbs 1970; Embley et al., 1970; Damuth 1975; Froelich et al., 1978; Milliman et al., 1982). They can be incorporated into the Orinoco supply and it is difficult to estimate their respective importance. Compared to terrigenous sediment, biogenic sediments are much less important. They are essentially composed of the tests of pelagic organisms; they represent from $5 \%$ to $45 \%$, but with an average around $10 \%$. Volcanic particles, a minor part of the sediment, are scattered through the muds. Finally, the mud diapiric processes constitute a final source of material whose importance is once again difficult to evaluate. Howewer, it is documented, in the vicinity of the mud volcanoes and the ridges, by particular clay mineral assemblages and by the presence of older material (Miocene to early Quaternary, Faugères et al., in press). Consequently, the South Barbados prism is subject to very important supplies because of the various sources and because of the proximity of a major continental source. The sedimentary structures of the deposits and microphysiography analyses show evidence that gravity processes (mainly turbidity currents) are the predominant dynamical factors. Typical pelagic deposits account for a minor part of sediments and are very limited in extent. Finally, very few signs of bottom-current activity have been found.

The different sedimentary patterns observed can be described by three principal groups (Plates 1, 2, and 3; Fig. 4):

1. Domains with regular, hemipelagic, or turbiditic surficial deposits and variable sedimentation rates such as depressions, basins, and the top of a few mud volcanoes or ridges (echofacies $\mathrm{El}, \mathrm{E} 2, \mathrm{E} 3)$;

2. Domains where transport and/or erosional processes are predominant, such as canyons or restricted areas situated on the edge of basins and domes or ridges (echofacies E3, E4);

3. Steep slopes or active tectonic zones where surficial deposits are strongly disturbed (echofacies E5).

\section{Echofacies E1}

E1 is characterized by a distinct echo and very regular continuous and parallel sub-bottom reflectors that sometimes converge upslope. These patterns are not very frequent. They are very well represented in the eastern part of the Orinoco map. They are localized on rather flat relief (poorly characterized ridges or suspended micro-basins, Fig. 2, no. 6 and Plate 2.2). They are also present in a few depressions far enough from major canyons such as the NW-SE depression (Fig. 2, no. 4 and Plate 1.2 and 1.3). This echofacies is typical of pelagic or hemipelagic deposits or of low-density and low-velocity turbiditic deposits. Samples collected here (68 and 66, Figs. 5 and 6 ) show that the surficial sediments are composed of medium-grained thin-bedded turbiditic layers interbedded with thick hemipelagic or muddy turbiditic layers.

\section{Echofacies E2}

E2 is a distinct echo but with more or less regular and continuous parallel sub-bottom reflectors that show good sediment penetration (generally more than $30 \mathrm{~m}$, Plates 1.4 and 2.3 ), often better than that observed in E1. This echo is largely found on depression and basin floors. It characterizes domains with high sedimentation rates and with sediments deposited by highdensity and high-velocity turbidity currents. This is confirmed by Cores (51, 52, 60 and 62, Figs. 5 and 6 ), which show the deposition of turbidites with centimetric to decimetric and exceptionally metric thickness, that are coarser than in E1. They are overlain by strongly bioturbated, soft surficial mud.

\section{Echofacies E3}

E3 is an indistinct strong, prolonged echo with commonly no sub-bottom reflectors, except near the edge of echo E2 and E3 where discontinuous wispy sub-bottom reflectors occur. This echo is typical of high-energy environments such as channels, with either erosion or non-deposition processes, or coarse-grained lag deposits. This echo is found mainly on the canyon floors (Plates 1.2, 2.1, and 3.4). It is also present in some very localized sectors of basins as well as in erosional furrows, several hundred meters wide, at the base of mud volcanoes and anticlinal ridges (Plate 1.2). In canyons, cores show that this echo is associated with debris-flows (64, Fig. 6) and with different kinds of turbidites, mainly coarse- to medium-grained (80 and 79, Fig. 6), sometimes fine-grained (64, Fig. 6), and with decimetric to metric thickness. On bottom photographs, the floor appears to be covered by coarse sandy particles and shows current marks. They remain relatively soft as proved by bioturbations (Plate 5.4). In the basins, this echo is also linked to coarsegrained turbidites (57, Fig. 6) and to soft bioturbated floors, locally more or less indurated (Plate 5.5). It could also be caused by bottom-current activity, especially in the furrows as well as in areas covered by probable sediment waves (Plates 1.1, 2.5, and 3.5).

\section{Echofacies E4}

E4 shows regular overlapping hyperbola with similar or slightly varying elevations and no sub-bottom reflectors. It is relatively rare and very limited in extent, localized in restricted sectors of canyon floors or slopes of depressions and particularly on the edge (levees?) of canyons where a E4-E3 gradual transition is observed (Plates 1.1, 2.4, and 3.3). E4 could be due to erosional processes or to very low sedimentation rates in turbiditic or bottom current high energy environments. These conditions would produce an irregular floor morphology.

In addition to the erosional sectors underlain by E3 and E4, others are marked by an erosional surface cutting through subbottom reflectors. They are situated on the flank of canyons or on high reliefs. In the first case, they are a result of turbidity currents and document the very recent canyon course (Plate $3.4)$. In the second case, the erosion could be the result of bottom-current activity or of slumping (discussed in the following section (Plate 3.6). 


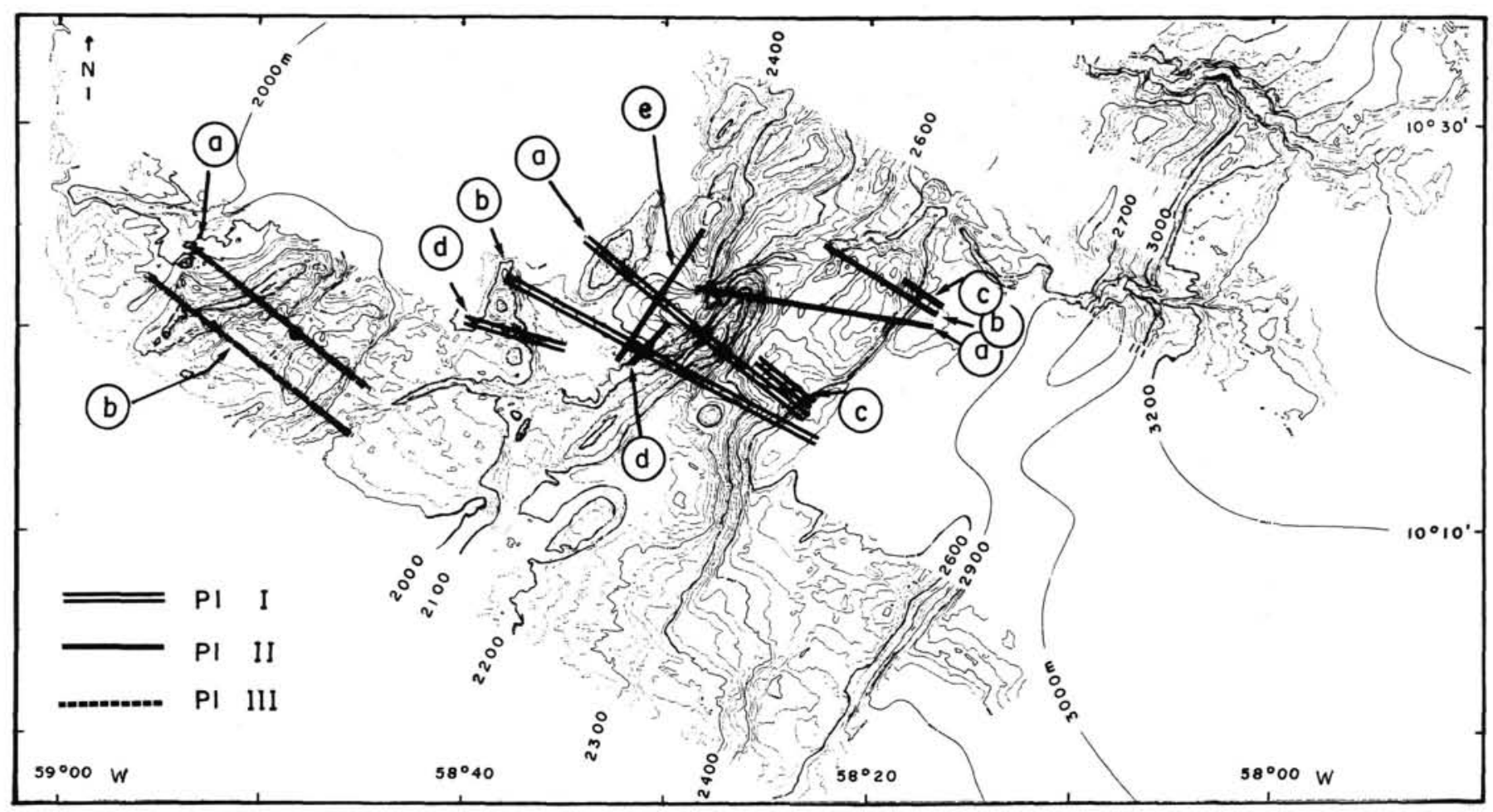

Figure 4. Orinoco map: location of $3.5-\mathrm{kHz}$ profiles. Depths in meters.

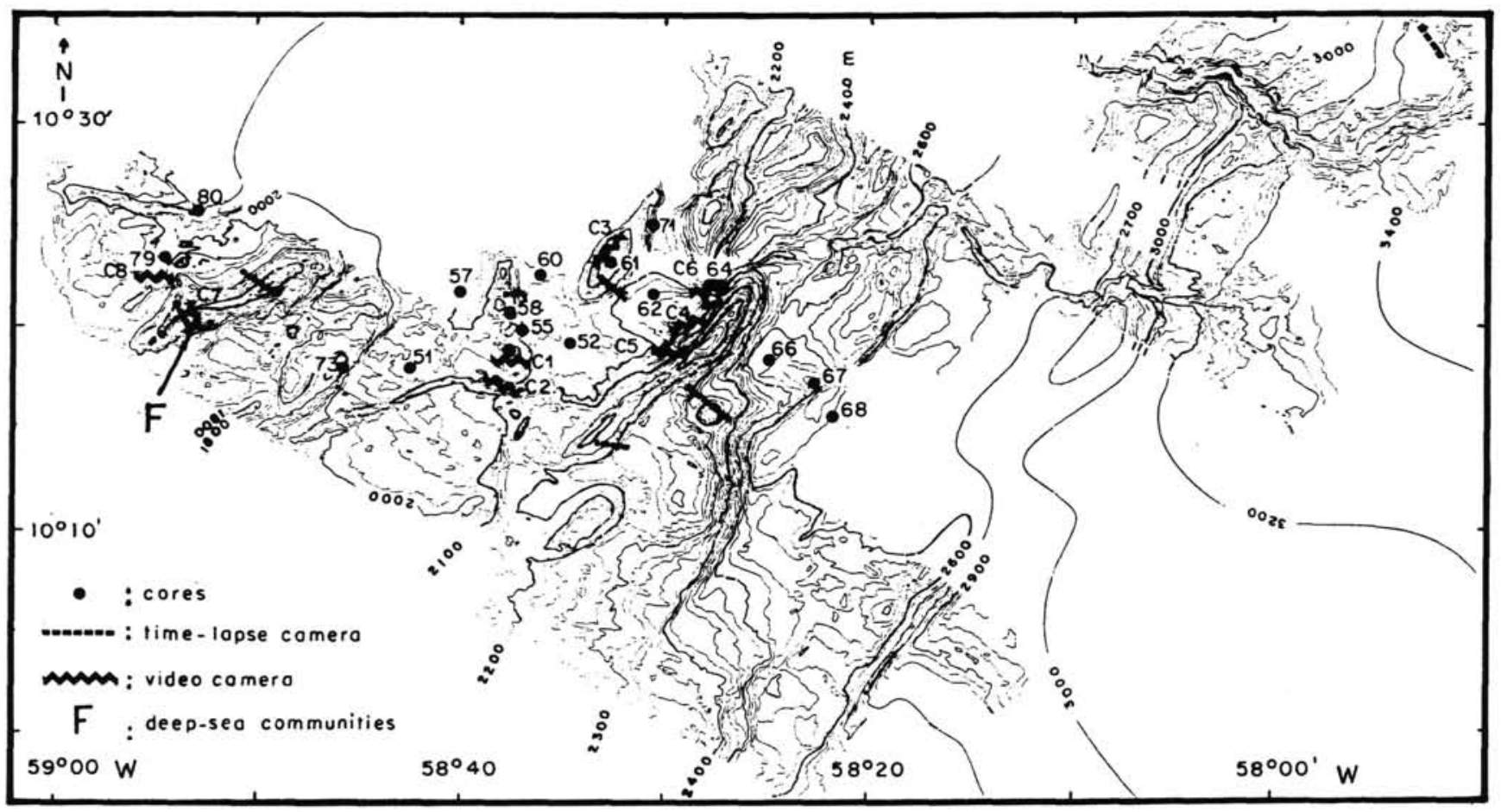

Figure 5. Orinoco map: location of cores, time-lapse camera, video camera, and deep-sea communities. Depths in meters.

\section{Echofacies E5}

E5 shows a deep and strong disturbance of surficial sediments. It is found in the contact zone between mud volcanoes, or anticlinal ridges and basins, or depressions. It is a conse- quence of both sedimentary and tectonic processes. In the first case, the steep slopes generate slides and this sliding material accumulates at the base of the relief, either forming well-characterized lenses among the basin regular deposits (Plate 2.3), or constituting surficial slump levees (Plate 1.4). In the second case 


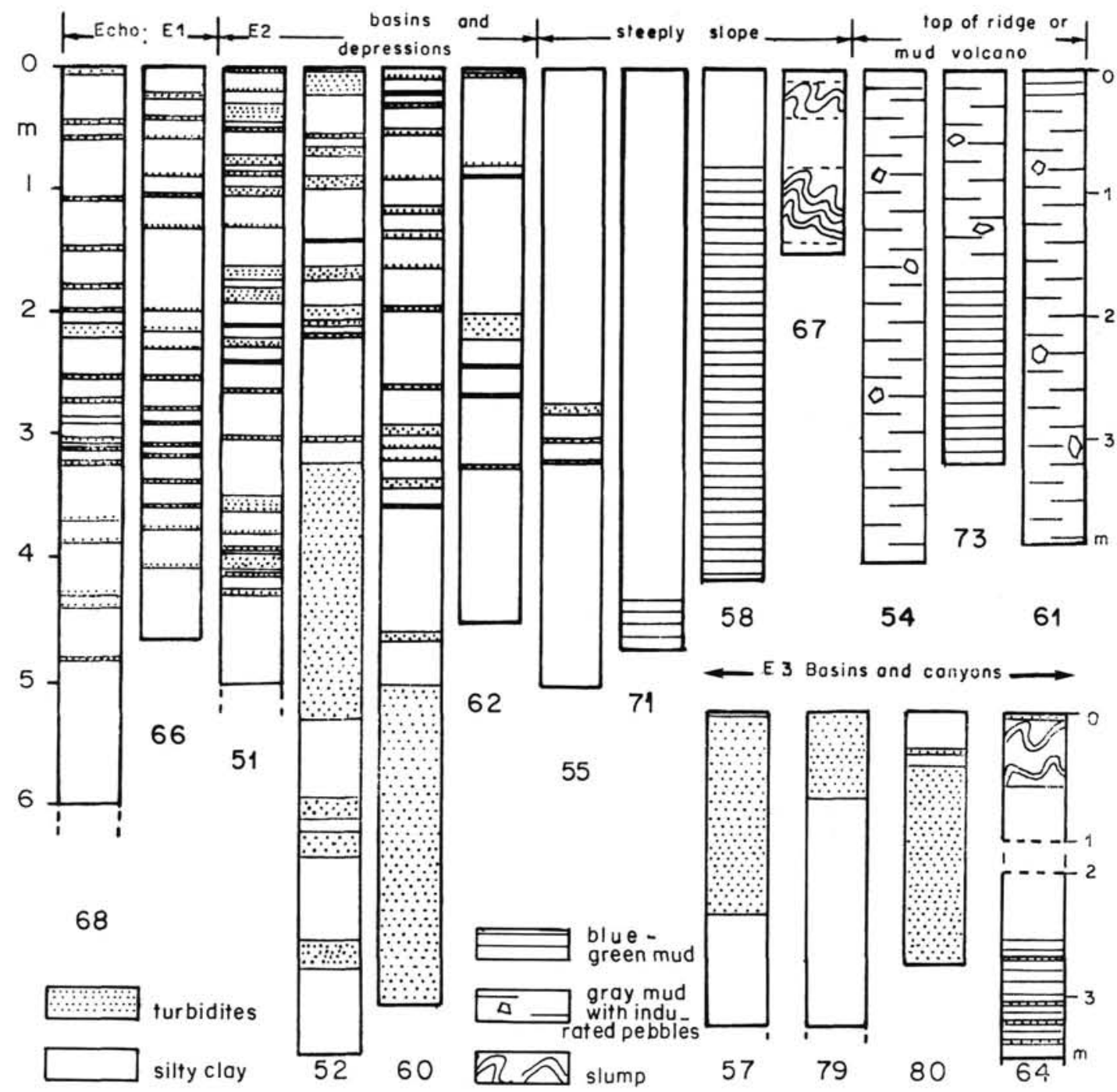

Figure 6. Core lithology.

(Plates 1.3 and 2.5), the contact zone is the site of an active structure, and a sharp contact exists between basin surface patterns (El or E2) and slope surface patterns. The latter case is probably the result of deposit disturbance by either fault activity or by the uplifting of diapiric clay material. Such tectonosedimentary processes are liable to generate olistolitic deposits that occur along the boundaries between active structures and adjacent basins. However, these deposits were in fact not found in our cores.

\section{Topographic Relief Surface Patterns}

Because of the relatively steep slopes of mud volcanoes and anticlinal ridges, $3.5-\mathrm{kHz}$ profiles yield very little information about the surface patterns of these features. Therefore, we have no information concerning the importance of mass-slides and the conditions in which they are generated. Cores taken on the flank (55 and 71, Figs. 4 and 6) usually show clayey-silty muds, Holocene to Quaternary in age, with rare interbedded finegrained turbidites. These deposits (58 and 71 , Fig. 6 ) overlie finer blue-green homogeneous muds that are also found in cores taken on the top of the mud volcanoes or anticline ridges. This barren material is probably older. Evidence of slumps was observed in a single core collected at the top of a fault escarpement
(67, Fig. 6). Bottom photographs show that the floors consist of soft mud, usually strongly bioturbated, with abundant worm tracks (Plate 5.3). Frequent evidence of bottom-current activity was observed: scour-marks, ripples, and coarse-grained ribbons (Plate 4.3 and 4.4). On the top of these reliefs, the floor shows specific sediment and faunal features. Simple sedimentary processes are not sufficient to explain them. Special geochemical conditions are necessary to produce these features and are discussed below.

In conclusion, the high continental sediment supply and the morpho-tectonic setting of the prism generate different sedimentary processes in all the previously defined domains. Within each of these domains, the joining of different echofacies shows very complex sediment distribution. In this way, for a basin that is a preferential sediment accumulation zone, deposits can be a result of (1) turbidity currents by overflowing of canyons with material coming directly from the Venezuelan margin, (2) massflows from the adjacent relief slopes, with material supplied by mud volcanoes or by turbidity currents of Venezuelian origin, and (3) contour currents that can rework and transport any sediments. The existence of a young morphological context, in perpetual reajustement, induces very active erosional sectors. At last, locally, recent structure activity disturbs the surface patterns of sedimentary origin. 


\section{DIAGENETIC PHENOMENA AND DEEP-SEA COMMUNITIES: EVIDENCE FOR PHYSICO-CHEMICAL CONDITIONS LINKED TO TECTONIC ACTIVITY}

Numerous bottom photographs were collected on top of several anticlinal ridges and mud volcanoes. They show that certain of these areas are affected by very spectacular biosedimentary features: indurated floors with irregular concretions on which deep-sea communities linked to cold seeps are usually found (Faugères et al., 1987).

\section{Surface Sediment Pattern and Associated Fauna}

A good example can be cited on the top of a NE-SW ridge in the Orinoco sector (Fig. 5). In its southern part, a camera track was made from the top toward the western slope, with depths varying from 1700 to $1750 \mathrm{~m}$.

\section{Camera Track}

The track shows a more or less indurated mud bottom and an E-W trend in the alignment of the various living organisms. Even though the community boundaries were not clearly observed, this track allows some reconstructions of its spatial and temporal variations through different sites (Plate 4.1 and 4.2; Plate 5.1 and 5.2; Fig. 7).

The summit's bottom is irregular with outcrops of hard sediment showing microcliffs (a few centimeters to a few decimeters high) and erosional marks, surrounded by soft bioclastic mud; the outcrops are covered by sponge and gorgonian colonies.

Further down, the main living community is concentrated within a 40 - to $50-\mathrm{m}$ band where the bottom surface is still more irregular. Cracked decimetric escarpments of compacted mud with dark, metal-like surficial crusts that probably hide cold seep fractures can be seen. On the flat top of these hard mounds, a bed of mussels is settled. On its base or in the fractures, vestimentiferan clusters, mytilid-like shells and a few serpulid polychaetes are nestled inside gaps. Some patches of soft conchitic sediment that are covered by probable mineral deposits surround those escarpments. Throughout this area, abundant dead vestimentiferan tubes and serpulid worms are embedded in rock outcrops, and empty shells are buried under collapsing soft sediment in a scarp depression (cemetery). Then, the fauna becomes scarce but diversified and the soft muddy sediments are more largely extended with an elongated cliff opening within a large graveled mud zone. At the foot of a slope break, a few large outcrops are still present and seem to be attractive centers for echinoderms. They are mixed with soft sediment, on the surface of which large empty shells are scattered irregularly.

Further down, the bottom slope decreases gradually toward a suspended basin; indurated bottom areas become less and less important but remain inhabited by an association of sponge or octocoralarian agregations and ophiuroids. A soft muddy substratum with rare empty shells shows progressive basin bottom characteristics, with deep endofaunal burrows and numerous holothurian tracks and local bottom-current ripple-marks.

\section{Cold Seep Communities}

Sponges and gorgonians are the most common organisms and extend from the top to the base of the ridge. These suspension feeders live on the indurated mud bottom. Sponges belong to, at least, three species of demosponges. The main species is distinguished by some isolated dark spherical shapes slightly bristled (spicules?). One other presents, in addition, abrased nodular excrescences. Numerous white arborescent gorgonians are established on the periphery of probably active cold seeps; large isidilid gorgonians are found in the vicinity of cemetery sites and probably less active or extinct cold seeps.

Large mytilid beds occur at the base of microescarpments. Small groups of clams, which are surrounded by Vestimentiferans, are scattered into cracks. Mussels, up to $20 \mathrm{~cm}$ long and characterized by an oblong dissymetric shell, are similar to Gulf of Mexico's mytilid clams (Hecker, 1985) and could be close to the Bathymodiolus genus of the hydrothermal vents. These beds seem composed of living and dead animals of various size. Dark erected shells with visible mantle tissue are mixed with large, light shells that are also found in the cemetery and seem to have undergone dissolution. In deposits, numerous buried open valves seem to be related to vesicomyid clams. A few scattered shells are ovoidal, fenestrate, and unusually tiny for the family.

Vestimentiferans are not bound in thickets like giant tube worms of the hydrothermal vents, but possess some of the external features of Escarpia (Jones, 1985) described from a Florida escarpment seep site. These long thin tube worms $(2 \mathrm{~m})$, are embedded in cracks on the indurated bottom and aligned with current direction. The apparent plume assigned to distal extremity fits the assumption of live animals, except in the cemetery where grayish decayed tubes are seen. There, most of the vestimentiferan and serpulid tubes cover rock outcrops and show the recent destruction of a dense assemblage. On active steep mounds, several serpulid polychaetes and some clusters of small pogonophorans, which could be a juvenile form of those depicted, are present. Organisms associated with this cold seep community include scarce galatheid crabs, anemones, holothurians, and monoaxonic organisms. The last ones (hexactinellid sponges or Pennatularians) are numerous on the boundaries of the community; they colonize soft sediment in the vicinity of probably active seeps and seem to form a sort of forest on extinct sites. No shrimps or gastropods were found there.

Furthermore, a typical deep-sea fauna, composed of classical bathyal fishes (Bathypterois and brotulidae or moridae fish), asteroid and ophiuroid organisms, is scattered all around the studied site. One surprising association of colonial "ear shaped" organisms in which live many ophiuroids (Plate 5.2), lead us to hypothesize a possible carbon source for this sessile species and a trophic relation between ophiuroids and these organisms.

\section{Discussion}

The featured seep community, dominated by large mussels, clams, and vestimentiferans, is closely related to the communities of cold sulfur seeps of other areas: Florida escarpment (Paull et al., 1984; Hecker, 1985), hydrocarbon seeps on the Louisiana continental slope (Kennicutt II et al., 1985) and Barbados abyssal mud volcanoes (Nautile dives, J. P. Foucher, pers. commun.). The main original faunal feature is the presence of a huge population of sponges and gorgonians that are mixed with classic bathyal fauna. Knowledge of the diet of such organisms (presence of symbionts or not) would permit us to state the chemical nature of seeps.

In Louisiana and Florida cold seeps, fauna use organic matter produced chemosynthetically in situ, by micro-organisms (mostly symbiotic) using sulfide and, as demonstrated in Louisiana (Fisher et al., 1987), methane. The mussel is the only animal with confirmed methanotrophic symbionts (Brooks et al., 1987) and we must be careful with too quick a generalisation. As noted in Florida escarpments, a very high content of sulfide occurs concurrently with high concentration of methane in seep areas (Lutz, pers. commun.). The joint occurrence of living clumps of mussels and cemetery lead us to hypothesize, taking 

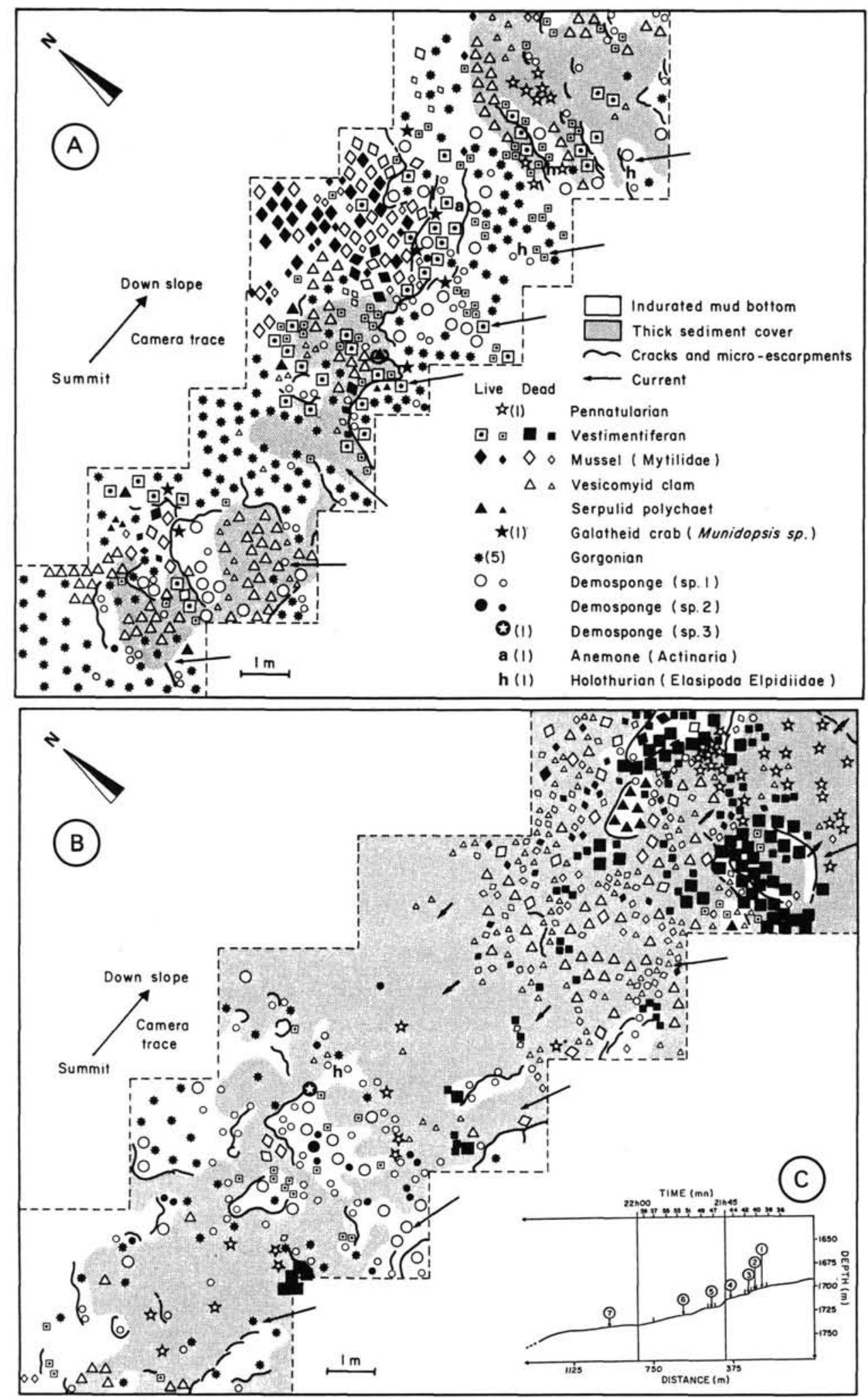

Figure 7. Microcartographic reconstruction of a camera-track portion from the top of an elongated NE-SW ridge in the Barbados accretion prism, showing a cold-seep community. The dashed lines correspond to the boundaries of a zone depicted by photo mosaic, but not to boundaries of the community. A: Active cold seeps show aggregations of living mussels and settlement of sponges, vestimentiferans, and gorgonian organisms on indurated mud microescarpements. B: Assemblage of dead clams and decaying vestimentiferans tubes in a denivellement. The organisms settled on rock outcrops or are buried in mud. C. 1: Summit; uneven bottom setting of rough sediment; fauna is abundant and poorly diversified. 2: Cold seeps; dissimilar bottoms with indurated mud microescarpments; fauna is very abundant and diversified. 3: Cemetery; collapsing soft sediment; abundant buried fauna with decrease of living organisms. 4: Zone of transition; irregular bottom with elongated cliff; fauna is scarce but diversified. 5: Extinct site; soft sediment covered by empty shells with rock outcrops; poor diversity of fauna. 6: Slope; gravel mud bottom with bottom current's marks and indurated chips; fauna is scarce and poorly diversified. 7: Bathyal Field; mudstone substratum with bioturbation-scattered bathial organisms. 
into account the rapid dissolution of dead shells, a very patchy and brief seep phenomenon. The presence of thickets of dead vestimentiferan tubes, rapidly decaying, strengthens this idea.

\section{Lithological Features of Indurated Floors and Surficial Sediment at the Top of Mud Volcanoes and Ridges}

A few samples of indurated bottom sediments have been collected. They are rocky pebbles, very strongly indurated with an irregular brownish colored surface. In thin sections, pebbles show a micritic microfacies with scattered pelagic foraminifers. They are coated with a very thin black deposit composed of iron and manganese oxides. These oxides also fill numerous microfractures of the calcitic micritic matrix, (Griboulard et al., 1989). Unlike adjacent or underlying soft sediments, the induration is due to calcareous cementation inside the soft mud and to iron and magnesium chemical precipitation at the surface of the deposits. These processes are responsible for irregular hardground with centimetric to decimetric microrelief as noted previously. For these authigenic deposits to remain on the surface, they must be swept by bottom currents or are the result of rapid lithification. In some sectors of the Orinoco and El Pilar maps, the irregularities of the indurated bottom are much more important, with microrelief of up to $1 \mathrm{~m}$. These floors present very well-developed crusts and concretions with a tabular or chimney shape (Griboulard et al., 1988). The chimney shapes evoke similar construction in the vicinity of hydrothermal vents (Rona et al., 1986). On the top of mud volcanoes or ridges, these constructions would be the result of successive deposits of metalliferous crusts, formed close to active cold seeps.

The geographic extent of these indurated grounds seems much more important than was thought (Faugères et al., 1987); i.e, these bottoms were observed in identical topographical position, on two sites belonging to the same ridge and at a distance of about $10 \mathrm{~km}$ (Fig. 5). Therefore, we have good reason to suppose that more or less discontinuous hard-grounds are present along most of the ridge, that is to say about $20 \mathrm{~km}$. On each site, they extend from the top toward the western slope of the ridge, for about $500 \mathrm{~m}$. We could assume that, at the scale of the ridge, these hard-grounds constitute an elongated band of about $10 \mathrm{~km}^{2}$. Furthermore they have also been found on top of other anticlinal ridges as well as on some isolated mud volcanoes. On the whole these indurated floors represent a very important surface on the South Barbados prism.

The soft sediments cored on top of these reliefs are composed of a surficial soft, recent mud, a few to $30 \mathrm{~cm}$ thick, overlying much older sediments that show two different aspects.

\section{Clayey-Silty Gray Muds}

These have a low carbonate content $(<10 \%)$, containing numerous indurated granules and pebbles. These rocky fragments are micritric limestone that have the same color and composition as the gray muds. As for the hard-grounds, they would be a result of a diagenetic carbonated cementation within the clayeysilty material. These sediments include Miocene to Quaternary planktonic microfauna (54 and 61, Fig. 6).

\section{Blue-Green, Clayey-Silty Muds}

These have a slightly higher carbonate percentage (about $15 \%$ ) and contain sandy, silty lenses that could be due to bioturbations; they hold very few planktonic foraminifers and could not be dated with precision; at the opening of the core liners a strong smell emanates, evidence of expansion of $\mathrm{H}_{2} \mathrm{~S}(73$, Fig. 6 ). These muds were also found in sectors with a very low sedimentation rate or erosion marks as in canyons or on the slopes of mud volcanoes $(64,58,71$, Fig. 6).

Under the Holocene pelagic or hemipelagic blanket, the top of mud volcanoes as well as that of anticlinal ridges seem to be made of "ancient" sediments. Their presence would be the result of diapiric processes. In this way the oldest sediment raised would be Miocene in age and show clayey mineral assemblages different from those in recent Quaternary sediments (Faugères et al., 1989).

\section{Discussion}

The existence of deep fauna and the diagenetic process observed on the surface sediments as well as within ancient sediments of mud volcanoes and anticlinal ridges, require very particular physical and chemical conditions. Previous works have shown that these fauna are developed around cold seeps where the surging water is enriched in metallic ions as well as in mineral components (Kulm et al., 1986; Laubier et al., 1986; Boulègue et al., 1987). On the Barbados prism, those fluids whose complex circulation patterns within the prism are guided by the major faults (Blanc et al., 1988), are enriched in $\mathrm{CH}_{4}, \mathrm{Mn}$, and are characterized by waters with a low chlorinity with respect to that of ocean water (Blanc et al., this volume). On the El Pilarand Orinoco-studied sectors, such conditions are realized: degassing of $\mathrm{H}_{2} \mathrm{~S}$, degassing of $\mathrm{CH}_{4}$ whose oxidation could supply part of the necessary carbon for biosynthesis and carbonate cement deposits, presence of $\mathrm{Mn}$ and $\mathrm{Fe}$ that forms the observed crusts, and finally low chlorinity in interstitial waters of the collected cores (Griboulard et al., 1989). These fluids would only be produced at the level of very active tectonic zones where they play a major role in the deformations (Valery et al., 1985; Lallement et al., 1986; Le Pichon et al., 1985; Moore et al., 1987). Hard-grounds and associated deep fauna are consequently considered as markers of these actives zones. These markers are generally found on top of NE-SW ridges and rarely found on mud volcanoes. They are associated with ancient diapiric material. But the presence of this material is not necessarily itself sufficient to indicate the presence of fluids, as was shown by the absence of fauna and indurated floors on certain mud volcanoes. These structures are therefore supposed to be presently inactive and as we do not have a single indurated outcrop, we can suppose that they are long inactive. This is shown by mud volcanoes that are aligned in a N-S direction, which is probably the trend of ancient structures (Fig. 2). On the other hand, NE-SW structures are active. Moreover, E-W structures deforming NESW ridges could be the main direction along which the deformation is actually occurring. Such an assumption is confirmed by the very active mud volcanoes that deform the crescentshaped basins of the El Pilar map and that are also due to E-W transcurrent faults (Valery et al., 1985).

\section{GENERAL CONCLUSIONS}

The very complex morphology of the South Barbados prism is a direct consequence of its tectonic setting. Major structural features are distributed according to four main lineations (NESW, N-S, NW-SE and E-W). They are responsible for the subdivision of the prism into morpho-structural domains of limited extent: anticline ridges, mud volcanoes, basins and depressions, and canyons. These different domains are characterized by morphological irregularities that are a consequence of the recent activity of these structures: NE-SW ridges with a sigmoid crest or crescent-shaped depressions both induced by E-W transcurrent faults, NW-SE depressions that are intersected by NE-SW ridges, multileveled suspended basins limited by various tectonic structures that can be marked by isolated or aligned mud volcanoes, and canyon courses superimposed on the structures, whose meanderings document permanent tectonic movements. Each of these domains constitute different morpho-sedimentary units.

Large fluvial tributaries, such as the Amazon and, above all, the Orinoco River, subject the southern part of the prism to substantial continental sediment supply. In the basins that are 
preferential accumulation zones, sandy sediments are deposited by turbidity currents, triggered on the Venezuelan continental slope. Bottom currents play a minor part; they can rework the fine-grained fraction of turbiditic materials as well as mass-flow material sliding from the slopes of neighboring structures and could also transport particles of distant origin.

Mud volcanoes and anticlinal ridges show varied sedimentary covers: surficial pelagic or hemipelagic muds overlying fine turbiditic deposits similar to those found in the basins on the lower part of the slopes, or ancient diapiric material on the top.

The floors of the basins as well as the slopes of the structural highs are often very bioturbated by striking worm tracks, which provide evidence for the development of abundant benthic fauna. On a few localized spots, particularly on the slopes of some highs, the presence of sedimentary ripple marks can be attributed to deep bottom currents. The evolution of the structural regime, the existence of steep slopes, and the predominance of turbidity currents produce local erosional phenomena as well as important deposit disturbances.

Areas with very low sedimentation rates or under erosional conditions are found in different domains. Canyon thalwegs, with eroded flanks, cut sub-bottom reflectors belonging to these domains; they are therefore recent patterns and are subjected to permanent modifications as the structures evolve. Consequently, their depths, generally speaking, are relatively low but increase with the uplift of the structures. Their floors are carpeted by coarse-grained turbidites, which is evidence for turbidity currents of high velocity. These currents create the valley morphology and coarse-grained sediment transport toward the deeper part of the prism as well as the Atlantic abyssal plain that are important in this area.

At the edge of structural highs and basins, erosional furrows are frequently observed; they could be the result of the action of bottom-current activity. On the slope of these highs, erosional features are due to mass slumping, and by these processes mud diapiric material could be introduced within the basin deposits. A consequence of this is the frequent disturbance of the deposits along the edge of the basins. These characteristics can be enhanced by the movement of faults that bound these domains and the adjacent mud volcanoes or the anticlinal ridges.

Finally, on top of the mud volcanoes and anticlinal structures, the sea floor is frequently indurated and can even be covered by concretions with irregular, or with columnar or tabular shape that range from a few centimeters to a meter high. This sediment hardening is caused by the settling of an authigenic carbonate cement as well as of a surficial iron-manganese coating. Because of the great geographical extent of these indurated bottoms, they can be considered as a major sedimentological feature of the tectonic prism that was, until now, unknown. On these floors live deep fauna composed principally of an association of sponges, Gorgonians, mussels, vestimentiferan tubes, and serpulid worms. The presence of the fauna as well as of indurated bottom can be explained by the advection of deep fluids (cold seep) that follow active major structures. The distribution of these particular hard-grounds on the South Barbados prism, documents the structures that are actually the most active and that are oriented in a NE-SW and E-W direction.

\section{REFERENCES}

Aubouin, J., Tardy, M., 1980. L'Amérique alpine: le domaine caraïbe et ses liaisons avec les cordilléres Nord et Sud Americaines. 26 siéme Conlgrés Géol. Inter., Mémoires B.R.G.M, 115:14-17.

Baretto, L. A., Milliman, J. D., Amaral, C. A., and Francisconi, O., 1975. Part Il, Northern Brazil. In Milliman, J. D., and Summerhayes, C. P. (Eds), Upper Continental Margin Sediments Off Brazil. Stuttgart (Schweizerbart), 11-43.

Belderson, R. H., Kenyon, N. H., Stride, A. H., and Pelton, C. D., 1984. A braided distributary system on the Orinoco deep-sea-fan. Mar. Geol., 56: 195-206.
Biju-Duval, B., Le Quellec, P., Mascle, A., Renard, V., and Valery, P., 1982. Multi-beam bathymetric survey and high resolution seismic investigations on the Barbados ridge complex (Eastern Caribbean): a key to the knowledge and interpretation of an accretionary wedge. Tectonophysics, 80:275-304.

Blanc, G., Gieskes, J. M., Vrolijk, P. J., Mascle, A., Moore, C. K., Taylor, E., Alvares, F., Andreieff, P., Barnes, R., Beck, C., Behrmann, J., Brown, K., Clark, M., Dolan, J., Fisher, A., Hounslow, M., McClellan, P., Moran, K., Ogawa, Y., Sakai, T., Schoonmaker, J., Willens, R., Williams, C., 1988. Advection de fluides intersticiels dans les séries sédimentaires du complexe d'accrétion de la Barbade (Leg 110, ODP). Bull. Soc. Geol. France, 3:453-460.

Boulègue, J., liyama, J. T., Charlou, J. L., and Jedwab, J., 1987 Nankai-trough, Japan trench and Kuril trench: geochemistry of fluids sampled by submersible "Nautile." Earth Planet. Sci. Lett., 83: 363-375.

Bouysse, P., 1984. The Lesser Antilles Island Arc: structure and geodynamique evolution. In Biju-Duval, B., Moore, J. C., et al., Init. Repts. DSDP, 78A: Washington (U. S. Govt. Printing Office), 83103.

Bowles, F. A., and Fleischer, P., 1985. Orinoco and Amazon river sediment input to the eastern Caribbean Basin. Mar. Geol., 68: 53-72.

Butterlin, J., 1977. Géologie structurale de la région des Caraibes. Masson.

Brooks, J. M., Kennicut Il, C. R., Fisher, S. A., Macko, K., Cole, J. J., Bidigare, R. R., and Vetter, R. D., 1987. Deep-Sea hydrocarbon seep communities: evidence for energy and nutritional carbon sources. Science, 238:1138-1142.

Chennouf, T., 1987. La terminaison Sud de la Barbade (Marge active des Petites Antilles). Etude des relations tectonique-sedimentation par application de la stratigraphie sismique [Thése]. Université de Paris 6., France.

Damuth, J. E., 1975. Echo-character of the western equatorial Atlantic floor and its relationship to the dispersal and distribution of terrigenous sediments. Mar. Geol., 18:17-45.

Damuth, J. E., and Hayes, D. E., 1977. Echo-character of the east Brazilian continental margin and its relationship to sedimentary processes. Mar. Geol., 24:M73-M95.

Eisma, D., Van der Gaast, S. J., Martin, J. M., and Thomas, A. J., 1978. Suspended matter and bottom deposits of the Orinoco delta: turbidites, mineralogy, and elementary composition. Neth. J. Res., 12:224-251.

Embley, R. W., and Langseth, M. G., 1977. Sedimentation processes of continental rise of north-eastern South America. Mar. Geol., 25: 279-297.

Embley, R. W., Ewing, J. I., Ewing, M., 1970. The Vidal deep-sea channel and its relationship to the Demerara and Barracuda abyssal plains. Deep-Sea Res., 117:539-552.

Faugères, J. C., Gonthier, E., Parra, M., Pons, J. C., and Pujol, J. C., 1989. Les apports du diapirisme argileux dans la sédimentation d'un prisme d'accrétion: la Ride de la Barbade, au sud-est des Petites Antilles. C. R. Acad. Sci., Paris, t. 308, S. II; 747-753.

Faugères, J. C., Desbruyères, D., Gonthier, E., Griboulard, R., Poutiers, J., Resseguier de, A., and Vernette, G., 1987. Témoins sédimentologiques et biologiques de l'activité tectonique actuelle du prisme de la Barbade. C. R. Acad. Sci., Paris, t. 305, s. II:115-119.

Fontas, P., Valery, P., Le Quellec, P., Mascle, A., Renard, V., Tardy, M., and Biju-Duval, B., 1984. Multibeam bathymetric survey of the Leg 78A drilling area and comparison with the southern part of the Barbados Ridge deformation front. In Biju-Duval, B., Moore, J. C., et al., Init. Repts. DSDP, 78A: Washington (U.S. Govt. Printing Office), 63-78.

Fontas, P., Griboulard, R., Prud'Homme, R., 1985. Morphogénèse d'un prisme d'accrétion et variabilité du style des déformations sur une marge active. Apports et spécificité des résultats d'une analyse cartographique interprétative sur la ride de la Barbade. In Mascle, A., (Ed.), Géodynamique des Carabes, Paris (Technip Eds.), 221233.

Fisher, C. R., Childress, J. J., Oremland, R. S., and Bidigare, R. R., 1987. The importance of methane and thiosulfate in the metabolisme of the bacterial symbionts of two deep-sea mussels. Mar. Biol., 96:59-71.

Froelich, P. M., Atwood, D. K., and Giese, D. S., 1978. Influence of Amazon river discharge on surface salinity and dissolved silicate concentration in the Caribbean sea. Deep-Sea Res., 25:735-744. 
Gibbs, R. J., 1970. Circulation in the Amazone river estuary and adjacent Atlantic ocean. J. Mar. Res., 28:113-132.

Griboulard, R., Faugères, J. C., Blanc, G., Gonthier, E., Vernette, G., 1989. Nouvelles évidences sédimentologiques et géochimiques de l'activité actuelle du prisme Sud Barbade. C. R. Acad Sci., Paris, t. 308 , s. II:75-81.

Hecker, B., 1985. Fauna from the cold sulfur seep in the gulf of Mexico: comparison with hydrothermal vent communities and evolutionnary implications. Bull. Biol. Soc. Washington, 6:465-473.

Higgins, G. E., Saunders, J. B., 1974. Mud volcanoes: their nature and origin. Verh. Nature. Ges., Basel, 84:101-152.

Jackson, M., and Gallawoy, W., 1984. Structural and depositional styles of Gulf coast tertiary continental margins: application to hydrocarbon exploration. AAPG Continuing Education Course Note Series, No. 25:1-226.

Jacobi, R. D., 1982. Microphysiographie du Sud-Est de l'Atlantique Nord et ses conséquences pour la distribution des processus prés du fond marin et des faciés sédimentaires associés. Bull. Inst. Géol. Bassin d'Aquitaine, Bordeaux, 31:31-46.

Jones, M. L., 1985. On the Vestimentifera, new phyllum: six new species, and other taxa, from hydrothermal vents and elsewere. Bull. Biol. Soc. Washington, 6:117-158.

Kennicut Il, M. C., Brooks, J. M., Bidigare, R. R., Fay, T. L., Wade, T. L., and MacDonald, T. J., 1985. Vent type taxa in a hydrothermal seep region on the Louisiana slope. Nature, 317:351-352.

Kuim, L. D., Suess, E., Moore, J. C., Carson, B. Q., Lewis, B. T., Ritger, S. D., Kadko, D. C., Thornburg, T. M., Embley R. W., Rugh, W. D., Massoth, G. J., Langseth, M. G., Cochrane, G. R., Scamman, R. L., 1986. Oregon subduction zone: venting, fauna, and carbonates. Science, 231:561-566.

Laubier, L., Ohta, S., Sibuet, M., 1986. Découverte de communautés animales profondes durant la campagne franco-japonaise KAIKO de plongées dans les fosses de subduction autour du Japon. $C . R$. Acad. Sci., Paris, t. 303, s. 11, 2:25-29.

Lallemant, S., Lallemand, S., Jolivet, L., Huchon, P., 1986. Kaiko: l'exploration des fosses du Japon. La Recherche, 17:1345-1356.

Le Pichon, X., liyama, T., Chamley, H., Charvet, J., Faure, M., Fujimoto, H., Furuta, T., Ida, Y., Kagami, H., Lallemant, S., Leggett, J., Murata, A., Okada, H., Rangin, C., Renard, V., Taira, A., Tokuyama, H., 1985. La subduction du bassin de Shikoku et de ses marges le long du fossé de Nankaî (Japon méridional): résultats préliminaires du programme Kaiko, Leg 1. C. R. Acad. Sci., Paris, t.301, s. 11, 5:273-280.

Leonard, R., 1983. Geology and hydrocarbon accumulation, Columbus basin, offshore Trinidad. AAPG 67:1081-1093.

Mascle, A., Cazes, M., Le Quellec, P., 1985. Structure des marges et bassins caraibes: une revue. In Mascle, A. (Ed.), Géodynamique des Caraibes: Paris (Technip Eds.), 1-20.

Mauffret, A., Westbrook, G. K., Truchan, M., Ladd. J., 1984. The relief of the oceanic basement and the structure of the front of the accretionary complex in the region of sites 541,542 , and 543. In BijuDuval, B., Moore, J. C., et al., Init. Repts. DSDP, 78A: Washing ton (U.S. Govt. Printing Office), 49-72.
Milliman, J. D., Buttenko, J., Barbot, J. P., and Hedberg, J., 1982. Depositional patterns of modern Orinoco-Amazon muds on the northern Venezuelan shelf. J. Mar. Res., 48:643-657.

Moore, J. C., Mascle, A., Taylor, E., and ODP Leg 110 Scientific party, 1987. Expulsion of fluids from depth along a subduction zone decollement horizon. Nature, 326:785-788.

Ngokwey, K., Mascle, A., Biju-Duval, B., 1984. Geophysical setting of deep sea drilling project sites $541,542,543$, Leg 78A, Barbados accretionary prism. In Biju-Duval, B., Moore, J. C., et al., Init. Repts. DSDP, 78A: Washington (U.S. Govt. Printing Office), 39-48.

Paull, C. K., Hecker, B., Commeau, R., Freeman-Lynde, R. P., Neumann, C., Corso, W. P., Golubic, S., Hook, J. E., Sikes, E., and Curray, J., 1984. Biological communities at the Florida escarpement resemble hydrothermal vent taxa. Science, 226:965-967.

Poutiers, J., Faugères, J. C., Gayet, J., Gonthier, E., 1983. Apports des missions Orgon a la connaissance des phénoménes sédimentaires en domaine marin profond au Quaternaire récent. In Arnould, M., et Pelet, R., (Eds.), Géochimie Organique des sédiments marins d'orgon a Misédor: Paris (Eds. CNRS), 211-278.

Rona, P. A., Klinkhammer, G., Nelsen, T. A., Trefry, J. H., and Ederfield, H., 1986. Black smokers, massive sulfides and vent biota at the Mid-Atlantic Ridge. Nature, 321:33-37.

Stephan, J. F., Blanchet, R., Mercier de Lepinay, B., 1985. Les festons nord et sud Caraibes (Hispanola-Porto-Rico; Panama et ColombieVenezuela): des pseudo-subductions induites par le raccourcissement Est-Ouest du bati continental péri-Caraibe. In Mascle, A., (Ed.), Géodynamique des Caraibes: Paris (Technio Eds.), 35-51.

Valery, P., Nely, G., Mascle, A., Biju-Duval, B., Le Quellec, P., Berthon, J. L., 1985. Structure et croissance d'un prisme d'accrétion tectonique proche d'un continent: La ride de la Barbade au Sud de l'arc Antillais. In Mascle, A. (Ed.), Géodynamique des Caraibes: Paris (Technip Eds.), 173-186.

Van Andel, Jj. H., 1967. The Orinoco delta. J. Sedimentol. Petrol., 37: $217-310$

Westbrook, G. K., Smith, M. J., Peacock, J. H., and Poulter, M. J., 1982. Extensive underthrusting of undeformed sediment beneath the accretionary complex of the Lesser Antilles subduction zone. $\mathrm{Na}$ ture, 300:625-628.

Westbrook, G. K., Mascle, A., Biju-Duval, B., 1984. Geopysics and the structure of the Lesser Antilles Forearc. In Biju-Duval, B., Moore et al., Init. Repts. DSDP, 78A: Washington (U.S. Govt. Printing Office), 23-38.

Wright, A., 1984. Sediment distribution and depositional processes operating in the Lesser Antilles intraoceanic island arc, Eastern Caribbean. In Biju-Duval, B., Moore et al., Init. Repts. DSDP, 78A, Washington (U.S. Govt. Printing Office), 301-324.

Date of initial receipt: 16 May 1988

Date of acceptance: 13 April 1989

Ms 110B-167 


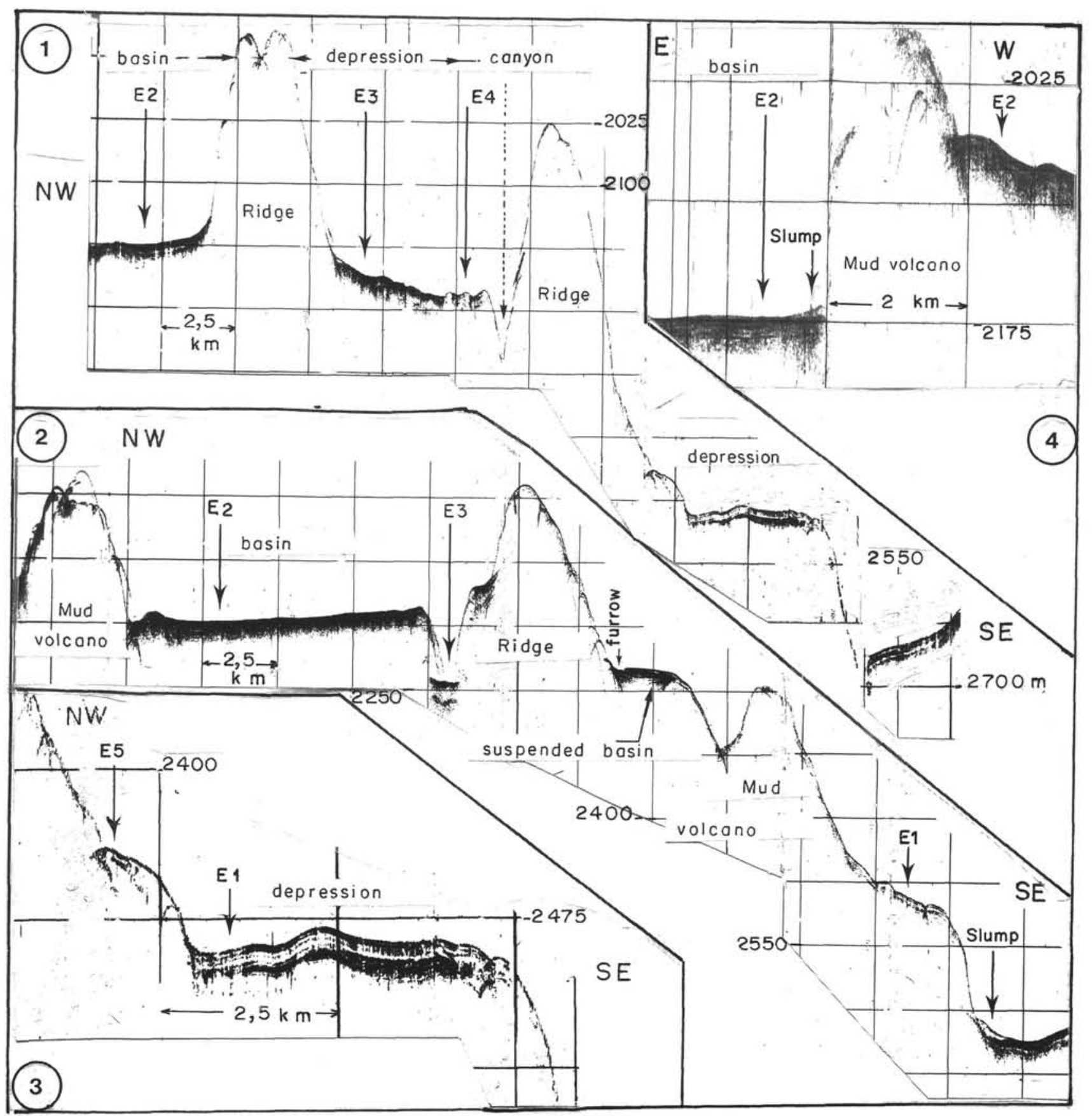

Plate 1. Profiles, $3.5-\mathrm{kHz}$, showing 1. Echofacies of basins and depressions intersected and offset by NE-SW ridges and faults or 4. Mud volcano incised by canyons ( 1 and 2 ) and with erosional furrows. Slumps ( 2 and $\mathbf{4})$ and disturbed contact zone (E5) are present between structural reliefs and basins (1 and 3). All these profiles are shown on Figure 4. 


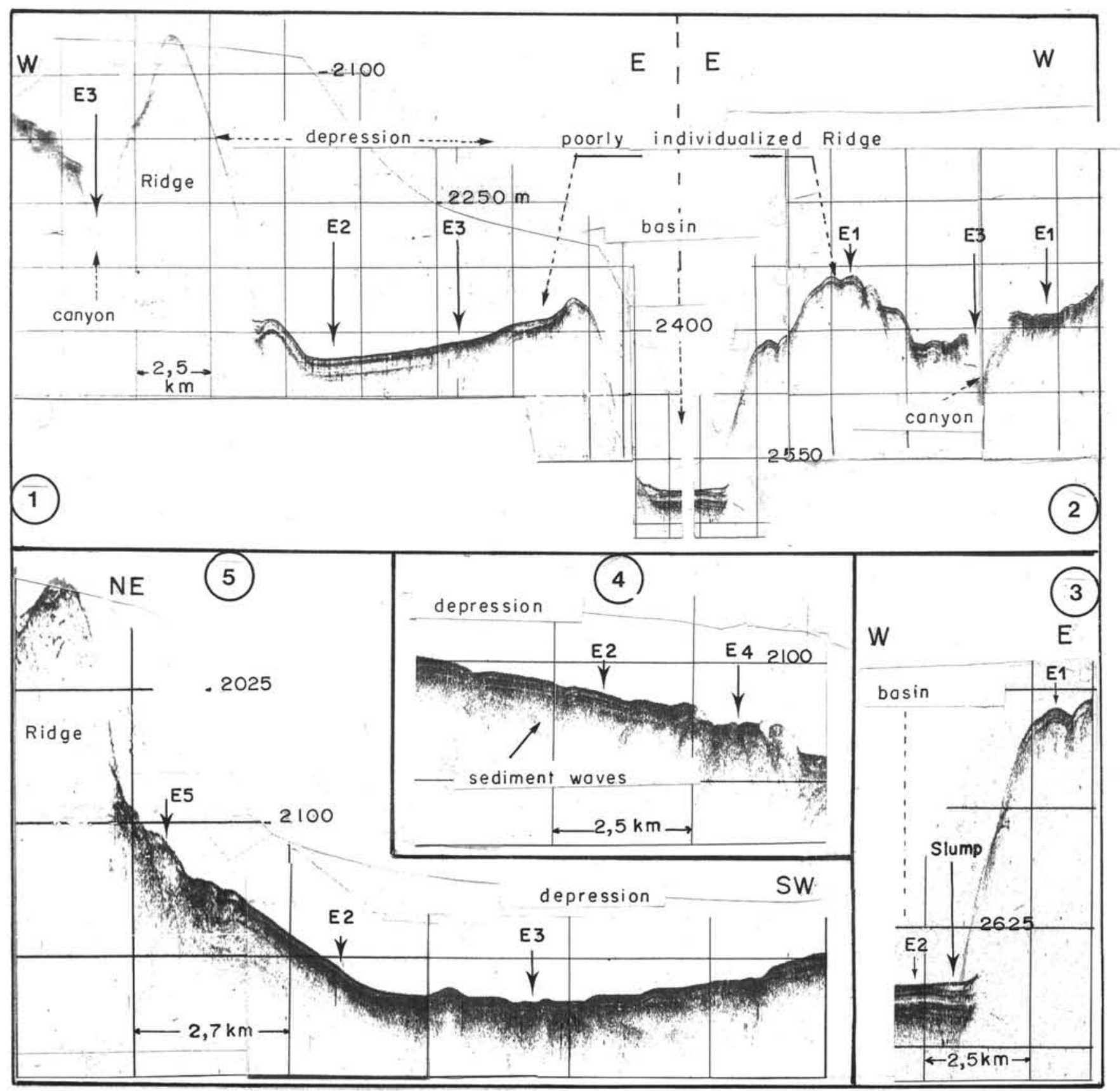

Plate 2. Profiles, 3.5-kHz: El echofacies on a weakly deformed ridge (2); E2 and E3 echofacies of basin and canyon floors (1); E2 and E4 echofacies gradual transition at the edge of a basin and a NW-SE depression (4); detail of lens-shaped slump (3); deformed deposits with E5, E2, and E3 echofacies in the contact zone between a ridge and a NW-SE depression (E). All these profiles are located on Figure 4. 


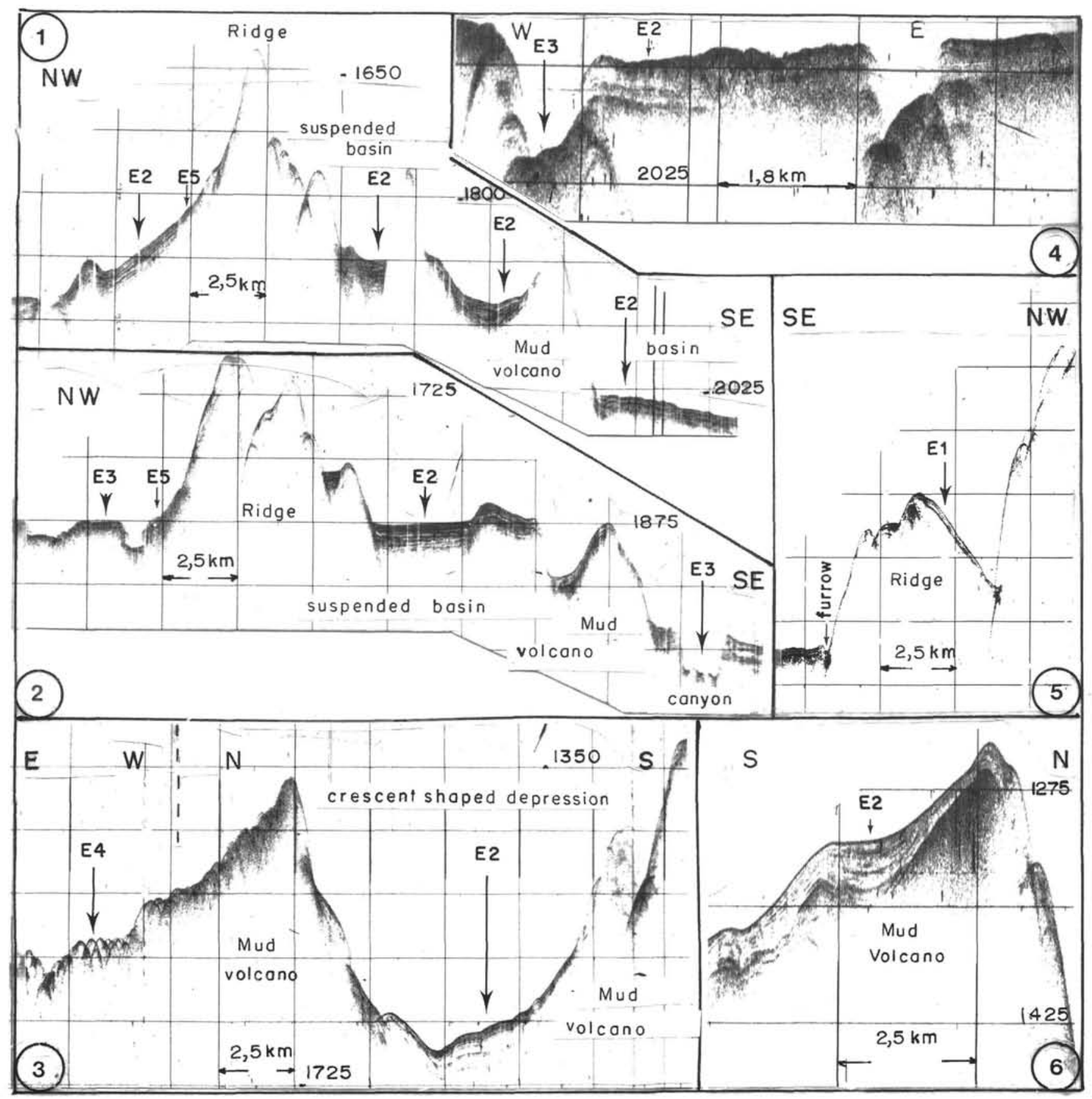

Plate 3. Profiles, 3.5-kHz: suspended basins with E2 echofacies between mud volcanoes and anticline ridges (1 and 2); erosional canyons with E3 echofacies (2 and 4); typical E4 echofacies on adjacent slopes (3); erosional furrows (5) and eroded slopes (6); E2 echofacies in a crescent shaped depression and typical E4 echofacies on adjacent slopes. All these profiles are shown on Figures 3 and 4. 


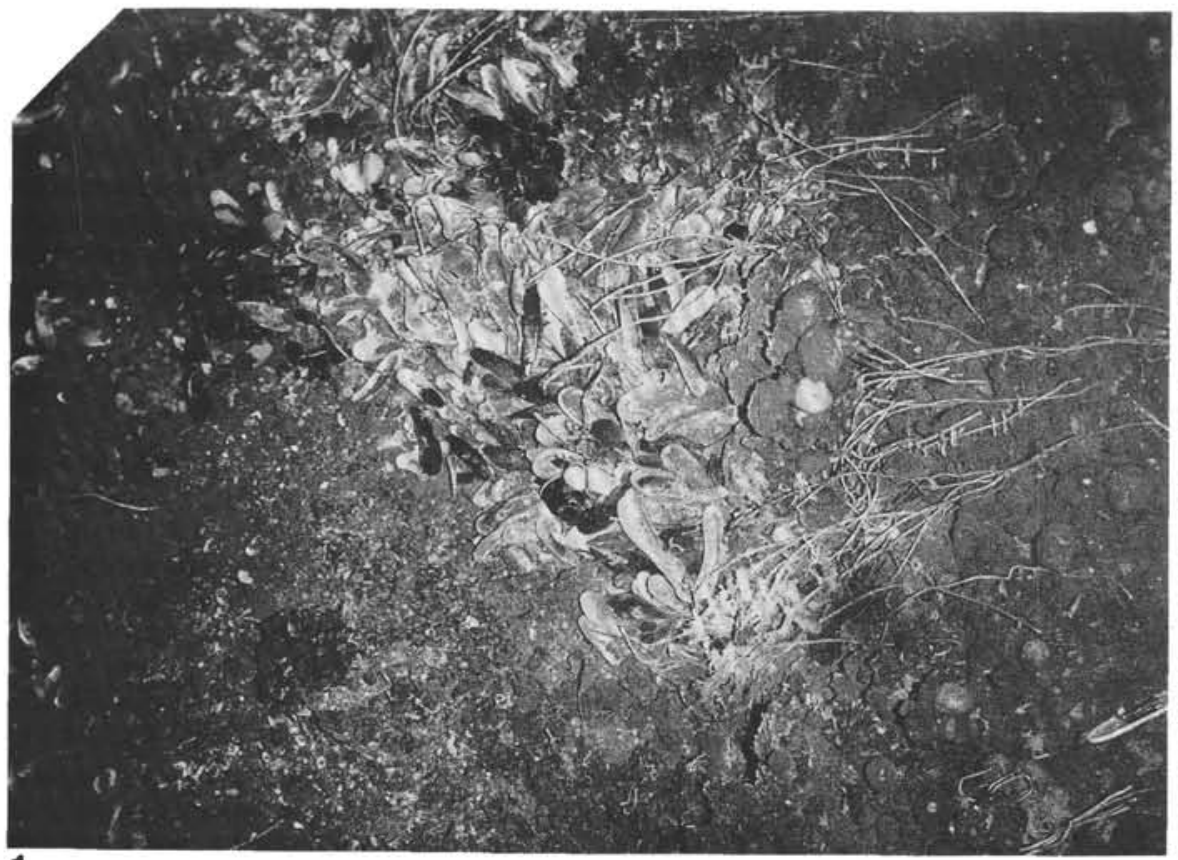

1
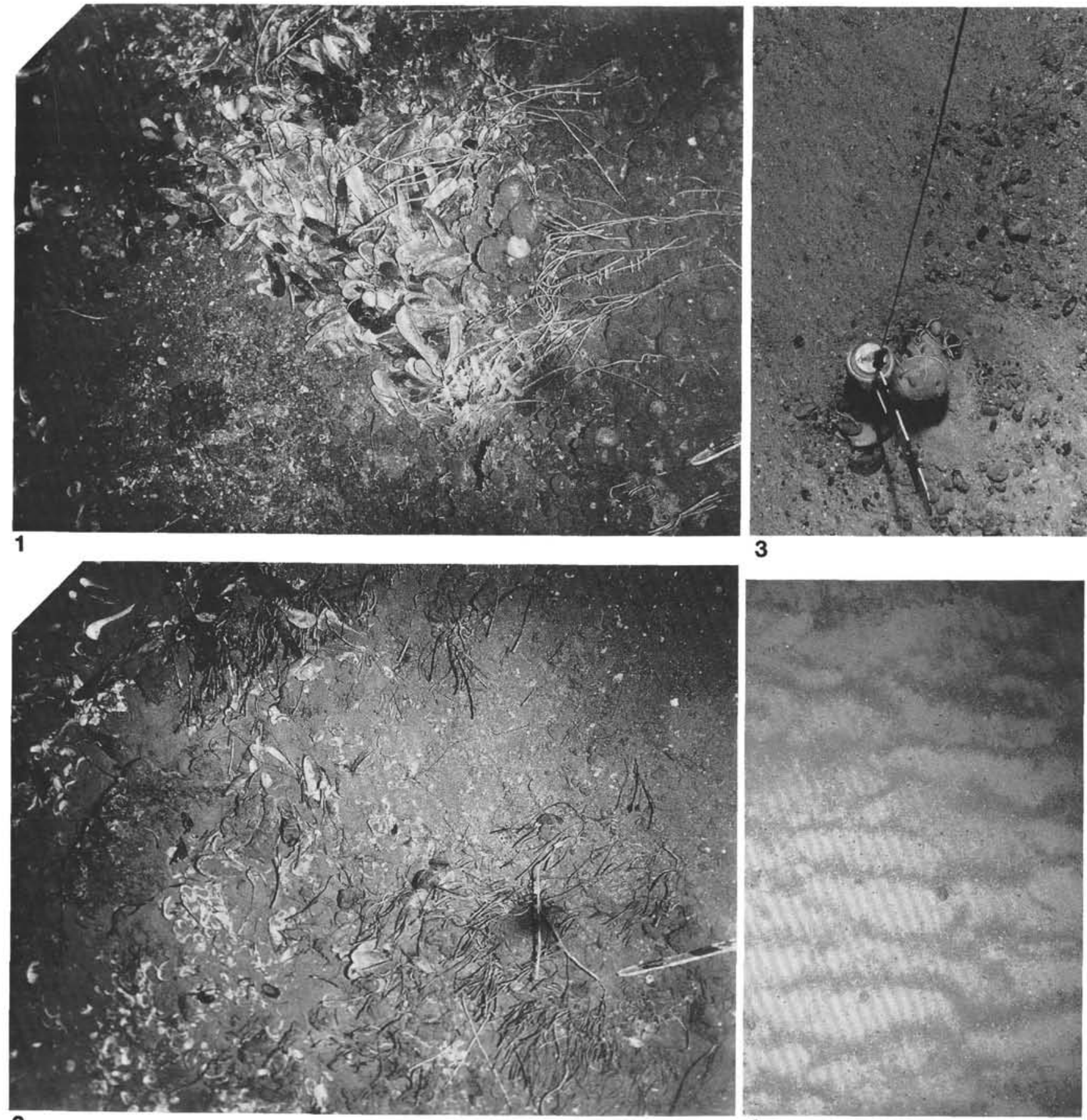

3

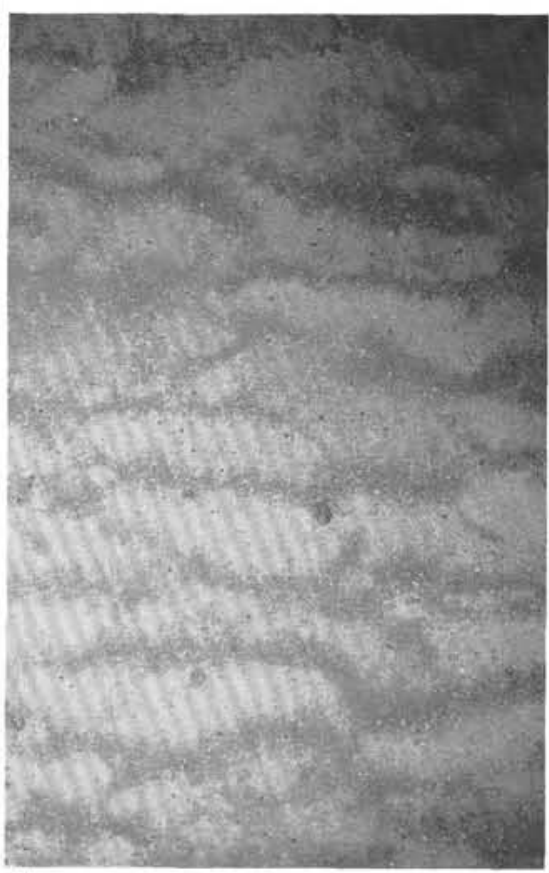

4

Plate 4. 1. Active cold seep: mussel bed with living and dead characters on a low-relief terrace under microescarpments on which settle Vestimentiferans and sponges. 2. Cemetery: scarp depression in which clams are buried and where rock outcrops are covered by serpulid Polychaetes and decayed vestimentiferans tubes. 3. Scour marks and gravel accumulation due to bottom currents. 4. ripple-marks on the flank of an anticline ridge; (scale, $1 \mathrm{~cm}=2.5 \mathrm{~cm}$ ). 

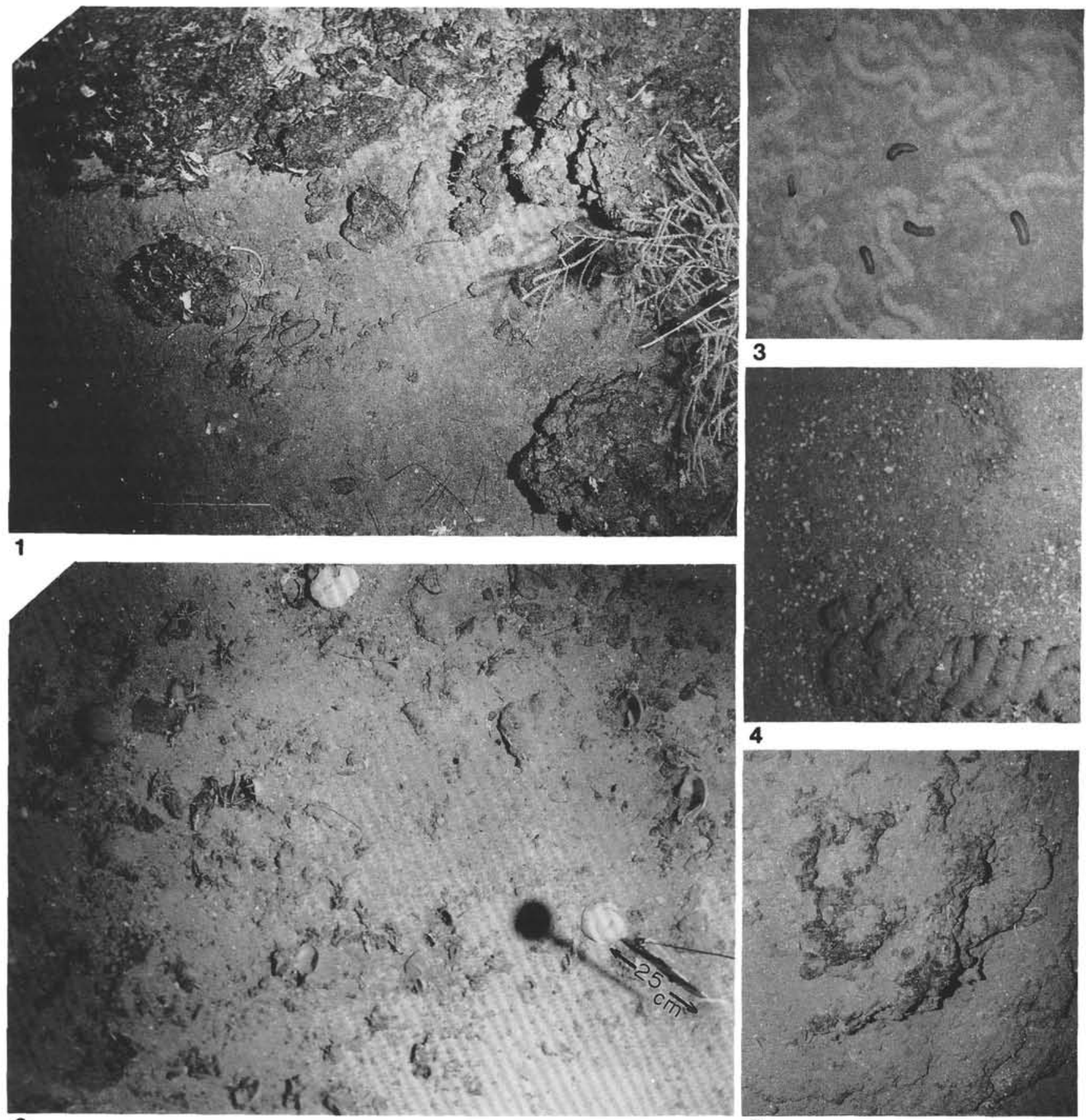

4

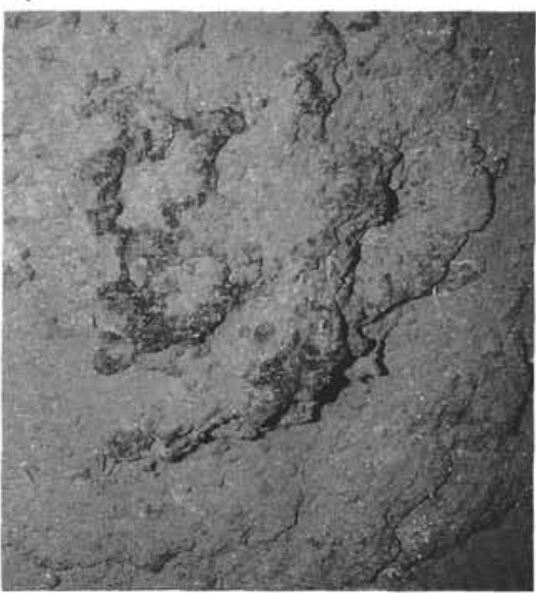

5

Plate 5. 1. Cliff in the vicinity of extinct site: escarpments where several paramucolid and isidilid Gorgonians settle. The presence of elpidilid Holothurians, galatheid crabs, sponges, and Pennatularians show a diversified fauna. 2. Downslope: surprising association of "ear-shaped" organisms (sponges or corals), Ophiuroids and Pennatularians in a bathyal environment that could show a possible carbon source for this assemblage. 3. Worm tracks and Holothurians on a depression floor. 4. Coarse-grained surficial sediments with an elongated fecal lump on a canyon floor. $\mathbf{5}$. Indurated floor at the edge of a depression and a canyon; (scale, $1 \mathrm{~cm}=2.5 \mathrm{~cm}$ ). 